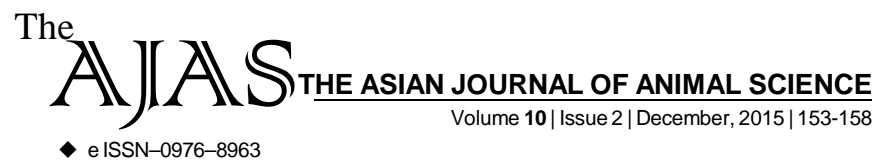

DOI : 10.15740/HAS/TAJAS/10.2/153-158 Visit us | www.researchjournal.co.in $\mathrm{S}$

RESEARCH ARTICLE.

\title{
Food and feeding habits of marine catfish, Osteogeneiosus militaris (Linn., 1758) off Mumbai waters
}

P.K. PARIDA, B.K. KHUNTIA, B.K. PATI, B. SAHU AND S.K. UDGATA

Author for Corresponding -

B.K. PATI

Department of Fishery

Engineering and Technology,

College of Fisheries (O.U.A.T.)

Rangeilunda, BERHAMPUR

(ODISHA) INDIA

Email: bikas_81@ rediffmail.com

See end of the article for

Coopted authors'
ABSTRACT...... The food and feeding habits of the marine cat fish, Osteogeneiosus militaris (Linn.,1758) off Mumbai waters was studied. The species was found to be carnivorous and predacious in feeding habit. Index of preponderance values indicated that, it feeds mainly on crustaceans (shrimps, crabs), molluscs (bivalves, squids) and small fishes (Coilia spp., ribbon fish). Among the food groups, crustaceans dominate throughout the year in comparison to molluscs and fishes. In the crustacean group, Acetes spp. was found to be the dominant food item contributing to 43.34 per cent followed by penaeid shrimps, which shared 27.65 per cent of the total food in all the months. Analysis of month-wise percentage food composition revealed that, the species fed the highest percentage of Acetes spp. during the month of November (34.92\%) while penaeid shrimps was consumed in the largest percentage in January (35.10\%). With respect to the size (length) of the fish, the percentage of Acetes spp. as a food item was highest (52.99\%) for the length group of 391-420 mm and lowest (25.64\%) for 361-390 $\mathrm{mm}$. The guts were found to be empty for fishes having length of more than $420 \mathrm{~mm}$. Results of the feeding intensity delineated that, the species is not a voracious feeder as none of the individuals studied was found to have gorged or full stomach over the entire period of investigation. Among the different length groups, the highest feeding fishes were in the length group of 211-240 mm. Gastro-somatic index was highest during August for males and during November for females while the pooled value was highest in January (3.206).

KEY WORDS...... Food and feeding habits, marine catfish, Osteogeneiosus militaris

HOW TO CITE THIS ARTIClE - Parida, P.K., Khuntia, B.K., Pati, B.K., Sahu, B. and Udgata, S.K. (2015). Food and feeding habits of marine catfish, Osteogeneiosus militaris (Linn., 1758) off Mumbai waters. Asian J. Animal Sci., 10(2): 153-158.

ARTICLE CHRONICLE - Received : 27.10.2015; Revised : 09.11.2015; Accepted : 15.11.2015 